\title{
ANALYSIS OF QUALITY INDICATORS OF CENTRAL STERILE SUPPLY DEPARTMENTS AT ACCREDITED PUBLIC HOSPITALS ${ }^{1}$
}

\author{
Suzimar de Fátima Benato Fusco², Wilza Carla Spiri
}

\begin{abstract}
${ }^{1}$ This work is part of a Master's dissertation under the title "Evaluation of the work processes of the Central Sterile Supply Departments of accredited public hospitals of the State of São Paulo: a case study", presented to the Faculdade de Medicina de Botucatu, UNESP - Univ Estadual Paulista, Departamento de Enfermagem, in 2008.

${ }^{2}$ Doctoral student in Nursing. RN, Departamento de Enfermagem, FMB/UNESP. São Paulo, Brazil. Email: sbenato@fmb. unesp.br

${ }^{3}$ Ph.D. in Nursing. Professor of the Departamento de Enfermagem, FMB/UNESP. São Paulo, Brazil. Email: wilza@fmb. unesp.br
\end{abstract}

\begin{abstract}
This study aimed to describe and analyze quality indicators of Central Sterile Supply Departments in Accredited Public Hospitals in São Paulo state and their management by those in charge of those departments. It is a multiple-case study, presenting interconnected data from three accredited hospitals in a report on cross-referenced cases. Data were collected by semi-structured interviews with the person in charge and by technical visits with documental analysis. Results showed the difficulty which those in charge have in identifying specific indicators for the department; the indicators mentioned relate to production and client satisfaction surveys, and do not describe the effective quality of the service, as they are fragmented and do not consolidate results in the search for improvement. This suggests low specificity and low sensitivity of the National Accreditation Organization criteria to this department's context.
\end{abstract}

KEYWORDS: Accreditation. Indicators of health services. Sterilization. Central supply, hospital.

\section{ANÁLISE DOS INDICADORES DE QUALIDADE DE CENTROS DE MATERIAL E ESTERILIZAÇÃO DE HOSPITAIS PÚBLICOS ACREDITADOS}

RESUMO: O objetivo do estudo foi descrever e analisar os indicadores de qualidade de Centros de Material e Esterilização de hospitais públicos acreditados do Estado de São Paulo e sua gestão pelos responsáveis do setor. Trata-se de um estudo de casos múltiplos, onde são apresentados os dados interligados de três hospitais acreditados num relatório de casos cruzados. Os dados foram coletados por entrevista semiestruturada com o responsável e por visita técnica com análise documental. Os resultados constatam a dificuldade dos responsáveis em pontuar os indicadores específicos do setor e os referidos foram os de produção e pesquisa de satisfação do cliente que não retratam a qualidade efetiva do serviço, pois são fragmentados, sem consolidação de resultados na busca de melhorias, o que sugere baixa especificidade e baixa sensibilidade dos critérios da Organização Nacional de Acreditação à realidade deste setor.

PALAVRAS CHAVE: Acreditação. Indicadores de serviços. Esterilização. Almoxarifado central hospitalar.

\section{ANÁLISIS DE LOS INDICADORES DE CALIDAD DE CENTROS DE MATERIALES Y ESTERILIZACIÓN DE HOSPITALES PÚBLICOS ACREDITADOS}

RESUMEN: El objetivo del estudio fue describir y analizar los indicadores de calidad de Centros de Materiales y Esterilización en los hospitales públicos acreditados en el estado de São Paulo y su gestión por los responsables del sector. Se trata de un estudio de casos múltiples, donde se presentan los datos vinculados a tres hospitales acreditados en un informe de casos cruzados. Los datos fueron recolectados a través de entrevistas semi-estructuradas con el responsable y por visitas técnicas con análisis documental. Los resultados señalan la dificultad de los responsables en la puntuación de los indicadores específicos para el sector y los indicadores mencionados estaban relacionados con la producción y la investigación de la satisfacción del cliente, que no representen la calidad efectiva del servicio, ya que son fragmentados y sin consolidación de resultados que busquen mejoras significativas, lo que sugiere una baja especificidad y sensibilidad de los criterios de la Organización Nacional de Acreditación a la realidad de este sector.

PALABRAS CLAVE: Acreditación. Indicadores de servicios. Esterilización. Central de suministros en hospital. 


\section{INTRODUCTION}

The Central Sterile Supply Department (CSSD) is defined as a technical support unit whose purpose is to provide appropriately-processed medical-hospital articles, thus providing conditions for direct attendance and health care provision for ill and healthy individuals. ${ }^{1}$

Recent advances in surgical techniques, and the responsibility for the control of infections, have placed the CSSD in a prominent position within the hospital. To fulfill this role, it is necessary to invest constantly in training, research and interaction with the units which it supplies, which are responsible for the tasks of prevention, diagnosis and therapy for their clients. ${ }^{2}$

In order to obtain quality, it is not sufficient to undertake all activities in the best way possible. With globalization, the importance of productivity has grown. Hence, as a result, much more is required of the people and the organizations, which has transformed quality from theory into practice. At the present time, Quality is a science which uses knowledge from mathematics, statistics, research, logic, information technology, administration, finance, psychology and many others. Among those who apply this new methodology, however, those who also do so with art, that is, with sensitivity, talent, perspicacity and devotion will stand out. ${ }^{3}$

Thus, it is fundamental for a method to be chosen which evaluates the quality of the health services such that, through its guidelines, there may be the possibility of undertaking the planning of the CSSD's work process so as to achieve the highest assistential standards.

Among the methods proposed in the literature one can find accreditation, a voluntary and periodical process undertaken and supported by the Brazilian Ministry of Health, through the Resolution described in Ministerial Ordinance GM n. 538 of $17^{\text {th }}$ April 2001, and which was implanted through the creation of the National Accreditation Organization (ONA) in 1999. ${ }^{4}$ This method, therefore, was developed exclusively for the hospital context and contains items specific for the CSSD. In this way, hospital accreditation becomes a guide for the health institution.

In one integrative literature review, $87 \%$ of the authors assert that the contribution of the accreditation lies in the change in the way that health care is provided, and that this fact leads to behavioral changes in the health team. As a result, the Accreditation program contributes to the oc- currence of a progressive and planned change of habits. With this, the professionals can be encouraged to participate in the process which aims for the mobilization and the creation of objective goals, with the aim of ensuring improvement in the quality of the care provided. ${ }^{3}$

It is important to emphasize that the emphasis of the evaluation is on the quality of the professional work provided, irrespective of the technological resources involved. The attendance must be guided by the criteria of excellence, taking advantage of the technology available, whatever it may be. This being the case, both public and private hospitals, located in big cities or in rural zones, have to adapt to the same quality standards. ${ }^{5}$

The standards established in the Hospital Accreditation $\mathrm{Manual}^{4}$ for evaluating the service for reprocessing of materials and sterilization, which identify if this is of good quality, are described separately, in accordance with the level of quality. For the purposes of this study, the Accreditation program's requirements related to the use of quality indicators which are required at levels 2 and 3 are listed, as follows:

Level 2: definition of the indicators for the processes identified; measurement and assessment of the results of processes.

Level 3: use of perspectives of organizational measurement, aligned with the strategies and correlated with the processes' performance indicators; existence of a system for making comparisons with relevant external references, as well as evidence of a favorable tendency for the indicators; new practices and improvements implemented, resulting from the process of critical analysis. ${ }^{4}$

As this is a quality evaluation program, it is hoped that the standards may address the use of quality indicators, as these are objective and defined measurements of that which is intended to be investigated, allowing one, through their results, to evidence problems and propose solutions such that these may not reappear. They are quantitative representations, occurrences or events of a system. They constitute a managerial instrument for measurement, without which it is impossible to rigorously evaluate quality or productivity. ${ }^{6}$

The construction of quality indicators for evaluating nursing services in hospital institutions entails the detailing of support references, in the light of which, different elements which make up the organizational structures, the work processes and the results of the care provided must be identified and analyzed.? 
Thus, the elaboration of these indicators requires a search for central ideas which point to the need to consider the following aspects: the care, educational and managerial health policies; the organizational mission and structure; the health institutions' programs and work proposals; the human, material, financial and physical resources available, and the expectations of the clientele attended. ${ }^{7}$

It should be emphasized that it is rare for one indicator, in isolation, to be capable of depicting the context. It is more probable that a group of them may reflect a specific situation. Thus, to ensure access to a set of indicators, it is fundamental for there to be an information system which can provide more and better elements for the construction and for the use of these. ${ }^{8}$

This investment requires an organized management process, with the appropriate tools and techniques, which plans the processes of the CSSD efficaciously and efficiently, which can be done through the identification of the "good practices" adopted by those responsible for this department in the Accredited Hospitals, which, under the terms of their certification, must comply with the pre-established standards, that is, must have indicators which aim for the improvement of quality and which may be used as guidelines for improving and bolstering the work undertaken, and also for avoiding unnecessary errors.

In this way, it becomes relevant to analyze the quality indicators used by the CSSDs of the Accredited Public Hospitals of the State of São Paulo, as well as to analyze the management of these indicators used by the nurses responsible for the Department, such that other units may benefit from these experiences and use them in their daily practice.

Therefore, the objective of this study was to describe and analyze the quality indicators used in the CSSDs of Accredited Public Hospitals and their management by those responsible for the Department.

\section{METHOD}

It is a multiple case study, ${ }^{9}$ presenting data from interlinked individual case studies in a report of cross-referenced cases.

A case study is defined as an empirical examination which investigates a contemporaneous phenomenon within its real-life context, especially when the borders between the phenomenon and the context are not clearly evidenced. ${ }^{9}$
Thus, the design proposed for this study was formed by a target-population which included all the Public Hospitals of the State of São Paulo which were accredited at any of the levels of quality in January 2008 - 10 in number - three being Accredited (level I), four Fully Accredited (level II), and three Accredited with Excellence (level III); ${ }^{10}$ they accepted voluntarily to participate in the research. The inclusion criteria were hospitals which had CSSDs in their facilities and which undertook the sterilization of at least $80 \%$ of their thermo-resistant articles. As a result, two hospitals were not included in the study.

The following strategy for entering the field was chosen: the sending of the research project in full to the hospitals, along with the decision of the Research Ethics Committee (OF. 99/ 2007 CEP) for evaluation by their research committees, which, following approval, forwarded them to the chief nursing officers for authorization. The maximum period stipulated for the hospitals' analysis and authorization was six months from the sending of the project. After acceptance, the researchers waited to receive the terms of consent signed by the responsible person, by post or by email, and the indication of the professional in the area to be interviewed. Telephone contact was made with the interviewee for arranging the interview and the form was sent to the interviewee by email or by post ahead of time. The interview and technical visit with documental analysis then occurred.

Data collection was undertaken in the period of January to March 2008 in three hospitals which had given authorization in the time period stipulated. All of the interviewees signed the Terms of Free and Informed Consent.

\section{RESULTS}

\section{Characterization of hospitals}

Table 1 lists some characteristics of the hospitals under study, designated as A, B and C, and the analysis of the set of these characteristics leads us to identify similarities among the hospitals so as to organize them in accordance with the complexity of their management, so as to situate the CSSD within this context.

The sample studied was characterized as Large-Size Hospitals* with structure and capacity directed at higher complexity care, with few years of activity and with three to five years of 
Accreditation certification, showing us that its organization was initially devised with quality in mind. This consideration also explains the fact of Hospital B already having level III of quality in only five years of existence.

For the CSSD, production is directly related to the number of beds, operating rooms and high complexity services, as the more numerous and complex the services offered are, the greater the demand and the complexity of the articles to be reprocessed.
As a result, the CSSDs investigated were classified according to the Resolution of the Collegiate Board (RDC) N. 15 of 2012, which concerns the requirements for good practice for the processing of products for health, in "Class II", that is, which undertakes the processing of noncritical, semi-critical and critical health products of complex and non-complex conformity, which may be reprocessed, ${ }^{11}$ showing the importance of the analysis of the hospital's characteristics for the dimensioning of this department.

Table 1 - Characteristics of the Accredited Public Hospitals of the State of São Paulo, 2008

\begin{tabular}{|c|c|c|c|}
\hline \multirow{2}{*}{ CHARACTERISTICS } & \multicolumn{2}{|c|}{ HOSPITALS } & C \\
\cline { 2 - 4 } & A & B & Between 03 and 05 years \\
\hline Time since Accredited & Between 03 and 05 years & Between 03 and 05 years & Level II \\
\hline Standard of accreditation & Level II & Level III & Large \\
\hline Hospital size & Large & Large & Over 30 \\
\hline N. of ITU beds & Over 30 & Oetween 10 and 29 & 05 \\
\hline N. of beds in Surgical Center & Over 8 & 04 & 01 \\
\hline High complexity services & 05 & Class II & Class II \\
\hline Classification of the CSSD & Class II & & \\
\hline
\end{tabular}

\section{Characterization of the interviewees}

The interview was held with those responsible for the area of CSSD, and these were characterized by their professional training, sex, age, time in the institution and time in the CSSD. This information allowed the description of a profile of the professional involved with managing the CSSD. Table 2 shows the variables described above, by hospital researched.

Table 2 - Characterization of the person responsible for the CSSD - Accredited Public Hospitals of the State of São Paulo, 2008

\begin{tabular}{|l|c|c|c|}
\hline \multirow{2}{*}{ CHARACTERISTICS } & \multicolumn{3}{|c|}{ HOSPITAL } \\
\cline { 2 - 4 } & A & B & C \\
\hline Professional training & Nurse & Nurse & Nurse \\
\hline Sex & Male & Female & 29 \\
\hline Age (years) & 27 & 24 & 5 \\
\hline Time in the Institution (years) & 3 & 6 & 3 \\
\hline Time in the CSSD (months) & 8 & 7 & \\
\hline
\end{tabular}

These are young nurses, with little time in the unit, which suggests turnover of these professionals in the area and difficulty of learning the work processes specific to this locale.

It was observed that the interviewees had great difficulty in indicating what the specific quality indicators are for CSSD. Generally speaking, the indicators specified had to do with production and client satisfaction surveys.

\section{Production indicators}

Table 3 shows the production indicators of the CSSDs of the hospitals studied, by sterilization method used.

* A hospital with between 150 and 500 beds. Translator's note. 
Table 3 - Production indicators by method of sterilization of the CSSDs of the Accredited Public Hospitals of the State of São Paulo, 2008

\begin{tabular}{|c|c|c|c|}
\hline \multirow{2}{*}{ Indicators } & \multicolumn{3}{|c|}{ HOSPITAL } \\
\hline & $\mathbf{A}$ & B & $\mathrm{C}$ \\
\hline \multicolumn{4}{|c|}{ Sterilization by saturated steam under pressure } \\
\hline Number of items of equipment & 04 & 03 & 02 \\
\hline N. of cycles/day & 26 & 20 & 17 \\
\hline N. of packages/month & 34,000 & 26,000 & 6,000 \\
\hline \multicolumn{4}{|c|}{ Sterilization by hydrogen peroxide plasma } \\
\hline Number of items of equipment & & 01 & 01 \\
\hline N. of cycles/day & & 03 & 07 \\
\hline N. of packages/month & & 1,000 & 2,500 \\
\hline \multicolumn{4}{|l|}{ Sterilization by ethylene oxide } \\
\hline Service tertiarized & Yes & Yes & No \\
\hline N. of packages/month & 15,000 & 2,500 & \\
\hline Cost/month & $\mathrm{R} \$ 18,000.00$ & $\mathrm{R} \$ 3,000.00$ & \\
\hline
\end{tabular}

Hospital A, with the highest production of articles sterilized using steam, also has the largest number of beds, the largest number of operating rooms and the largest number of high complexity services, followed sequentially by hospitals B and C.

Regarding the sterilization of thermosensitive articles, it was observed that hospital A does not have equipment for this purpose, therefore, this service is undertaken through a company which uses ethylene oxide sterilization, presenting monthly production which is high, but which is explained by the number of high complexity services which attend patients, for example, hemodynamic services and video-laparoscopic surgery.

Hospital B has sterilization equipment using hydrogen peroxide plasma (HPP), but also tertiarizes this service to a company which uses ethylene oxide sterilization. The separation of the articles to be sterilized by one method or another is in accordance with the recommendations of the manufacturer and the hospital's standardization. As HPP has limitations and a low penetration rate, the hospital needs another method of sterilization, in this case, ethylene oxide. Although this hospital has various high complexity services, its production is not high when compared to that of hospital A.

Hospital $C$ does not have hemodynamic services, and does not undertake video-laparoscopic surgery, which explains why there is no need for tertiarization using a sterilization company for thermosensitive articles. These articles have little complexity and are indicated to be sterilized using HPP, which was undertaken in the hospital itself, as this has equipment for this purpose. However, in contrast, this hospital was a center of excellence in traumatology and orthopedic surgery, involving a high complexity of reprocessing in the thermoresistant materials, including implants.

None of the CSSDs had equipment for sterilizing using Low Temperature Steam with Formaldehyde (LTSF).

\section{Client satisfaction survey}

Client satisfaction surveys are a major result indicator, as they assess the meeting of the clients' expectations and, mainly, the product produced by the CSSD in the view of the consumers.

In the hospitals studied, the client satisfaction survey was mentioned by everybody, who reported undertaking them systematically, every 30 days in hospital A and once every six months in hospitals B and C. Following the tabulation of their data, the interviewees mentioned the diagnosis of the principal errors and successes, and, through these, the generation of policies for improving quality in CSSD through changes in the processes and the undertaking of training. However, in the documental analysis, records were not found of change in the indicators after the instituted actions reported. In no hospital was this indicator measured with a positive prognosis.

Another factor to consider is that the satisfaction survey only covers the hospital's consuming units, but does not cover the providers or the internal clients, that is, the staff themselves. 


\section{The management of the quality indicators}

As already described above, the CSSD's quality indicators are not well defined in the hospitals studied. Production indicators and result indicators are reported but with different methodologies regarding the elaboration of the indicators, which describe fragments of the CSSD context. However, the use of the results obtained seems not to interfere in the continuation of the quality actions. The critical analysis of the indicators, with the establishing of cause-and-effect relationships among the indicators, and decision-making based on these analyses and on strategic planning were not mentioned in any of the hospitals in a systematic way and with records of this process.

No hospital researched had a system for comparing indicators with external points of reference related to the CSSD. This situation was reported by the interviewees as a difficulty due to the lack of standardization of the indicators, including hospital B, which has a Level III certificate of quality, in which this requirement is mandatory. The nurse at this hospital, possibly due to her little time in charge of the Department (seven months) did not know of the external references, but emphasized that this is a great challenge for the area.

\section{DISCUSSION}

The measuring of the CSSDs' production takes on special importance, both due to structural questions associated with the nature of its product, and due to operational questions which range from simple knowledge and comparison of its activity through to more technical questions, such as the evaluation of the quality of the reprocessing of the articles.

For the CSSD, production is directly related to the number of beds, operating rooms and high complexity services, as the more complex and numerous the services offered are, the greater the demand and the complexity of the articles to be reprocessed.

The methods of sterilization used in these CSSDs consider firstly the thermoresistance of the materials. Among the methods available, wet heat in the form of wet steam under pressure is the most reliable, and hence safest, method and that which unites the most advantages. Since 1950, however, materials with thermosensitive components, which require low temperature methods of sterilization, have become available in health care. The first automatized equipment for sterilizing thermosensitive materials in the health area was that which used ethylene oxide gas (EtO), followed by hydrogen peroxide plasma gas (HPPG), followed by LTSF and, more recently, ozone-based equipment. ${ }^{12}$

Comparatively, we observed that of the methods mentioned, sterilization by steam is that which is most indicated and used, as much in the hospitals studied as in the pharmaceutical industry and in the hospital area in general. ${ }^{13}$ It may also be verified in the literature $e^{13}$ that $90 \%$ of sterilized articles used in care are processed in steam autoclaves, which are not found in hospitals A and C, where the proportion is reduced to approximately $70 \%$. This is explained by the development of surgical techniques which require sophisticated, high-cost instruments, such as the development of video-surgery, with a significant impact on the increase of the number of single-use items to be reprocessed ${ }^{* *}$.

An ideal method of sterilization has not yet been developed. The technologies mentioned above have limits, advantages and disadvantages, as well as differences in the diffusibility of the sterilizing agent, incompatibilities with raw materials, toxicity and different cost-benefit ratios. ${ }^{12}$ This being the case, each hospital adopted technologies which best meet its context.

The indicators can constitute an instrument of strength and power to change internal work processes, when the collection and the results are treated appropriately. When this was not the case, we observed a quantity of information which does not cause improvements or revisions in the processes indicated, harming the department by failing to give rise to cycles of continuous improvement.

Such an approach harms the institution, in the extent that the actions come to be guided by short-term characteristics, rather than predictive characteristics, without a focus on the processes.

The quality of the processing of materials used in health care is one of the pillars of the control and prevention of infection, and relates as much to the ensuring of the materials being submitted to processes of microbial reduction or destruction as to their functionality and integrity, so as to avoid harm to the organism resulting from their use. ${ }^{14}$ In

\footnotetext{
** This is permitted in Brazil, under the terms of Resolutions RE N.2605 and RE N.2606 of 11th August 2006, and RDC N.156 of the National Health Surveillance Agency (ANVISA), also of 11th August 2006. Translator's note.
} 
the hospitals studied, indicators were not found which depicted this quality of the reprocessing of the materials and of the management of the CSSD.

One recent initiative elaborated eight indicators which cover the stages of processing materials used in health care (cleaning, preparation/ packaging, sterilization, storage/distribution) and encompass evaluations of structure, process and result. Each indicator presents the components to be evaluated, as well as how the data shall be obtained and the formula for calculating the measurement of compliance. ${ }^{14}$ These indicators offer the advantage of allowing the monitoring of the evolution of compliance in each institution, with a view to the continuous improvement of the quality. Once the acceptable standard of compliance has been achieved, it will be possible to undertake the comparative inter-institutional evaluations, as it is not possible to make comparisons of indicators with CSSDs of other institutions if the measurement units are different and not standardized.

RDC n. 15/2012,11 which regulates requirements for good practice for the processing of health products, could cover these indicators, while transferring to the professional responsible for the CSSD of the health service the competency to propose the indicators for control of the quality of the processing of the products under their responsibility, which once more gives rise to a plethora of protocols and the impossibility of making comparisons.

External comparisons, or benchmarking, although a requirement of the accreditation standards, remain little used for the reasons already given. One evaluation undertaken regarding the limiting factors for benchmarking between hospital organizations shows that the sharing of the knowledge is intrinsically linked to the human factor. According to the authors, in the United States there are large national databases which allow comparability between all the types of health service, including their costs and their results. ${ }^{15}$ In Brazil, the large majority of health services still resist providing information regarding their activities, either from fear of being copied, fear of their competitors, or fear of inspection or even, if it is the case, because they do not have the data and do not feel comfortable with this situation. ${ }^{16}$

Actions aligned with the strategic planning were also not mentioned by the interviewees. This result is not surprising, considering that one of the main obstacles in the area of health to the implementation of programs for continuous improvement is the absence of focus on them as a strategic priority.

Indeed, the work processes reported by the nurses are very close to this type of daily management involving scheduled activities. This observation does not reduce the intrinsic value of the quality of the activities undertaken, it simply demonstrates that instead of there being rigor in the recording and management of weak points, there persists a focus on the resolution of the immediate problems.

This practice leads to an invisibility of the CSSD, which is closely related to the invisibility of nursing as a profession, showing the need for engagement in the process of the profession's social construction, through a reflective praxis, overcoming the process of alienation resulting from this rote work. ${ }^{17}$ It is known, however, that a profession's visibility occurs in the daily construction of a practice which is based on tacit and scientific knowledge, leading to the emergence of social recognition. ${ }^{17}$

The management of the quality indicators allows the CSSD nurse to find responses to various managerial, assistential, economic and legal issues, which is not made totally possible by the ONA criteria, which have been shown to be little specific and little sensitive in the analysis of the CSSD's quality.

The results presented, however, are dependent on the sample, as they focus their attention on a few units of the universe, due to the fact that only three hospitals accepted to participate in the study. As a result, the results obtained must not be generalized to the other accredited hospitals, as each one can present differing work realities and contexts, due to Brazil's large situational and even structural divergences in the area of health.

On the other hand, it is recommended that the ONA, with the nurses responsible for the CSSD, should construct an evaluative methodology with clearer and more specific criteria and validate them, such that there may be standardization of the language and the variables, so as to facilitate its administration and later comparison, with a focus on the improvements.

\section{CONCLUSION}

The undertaking of this study made it possible, through the case study, to describe and analyze the quality indicators of three CSSDs of Accredited Public Hospitals of the State of São 
Paulo, concluding that, unfortunately, it was not possible to confirm the research's initial hypothesis, as it was sought in these hospitals to identify their "good practices" to be used as guidelines for other hospitals.

The results observed allow it to be inferred that the production and client satisfaction indicators, measured by these hospitals, do not depict the effective quality of the CSSD service, as they are fragmented and do not consolidate results in the search for improvement. Also un-identified were indicators for structure, process and results, which would bring a more scientific and less empirical connotation, as occurred with the sample.

\section{REFERENCES}

1. Silva A. Organização do trabalho na unidade de centro de material. Rev Esc Enferm USP. 1998 Ago; 32(2):169-78

2. Silva A, Bianchi ERF. Central de material e esterilização. In: Lacerda RA, coordenadora. Controle de infecção em centro cirúrgico - fatos, mitos e controvérsias. São Paulo (SP): Ateneu; 2003. p. 53-62.

3. Andrade FM, Bretas TCS, Freire MAF, Andrade JMO, Bastos AMF, Bakonyi S. Acreditação e a busca pela qualidade assistencial: uma revisão integrativa. Rev Dig Lect Educ Física Deportes [online]. 2012 [acesso 2013 Jan 29]; 15(166). Disponível em: http:// www.efdeportes.com/efd166/acreditacao-e-abusca-pela-qualidadeassistencial.htm

4. Organização Nacional de Acreditação (BR) [online]. Manual Brasileiro de Acreditação. $5^{\mathrm{a}}$ ed. Brasília (DF), 2006. [acesso 15 Set 2007]. Disponível em: http:// www.anvisa.gov.br/servicosaude/acreditacao/ manual/MA6_abastecimento_apoio_logistico.pdf

5. Bonato VL. Gestão de qualidade em saúde: melhorando assistência ao cliente. Mundo Saúde. São Paulo (SP): 2011 Mai; 35(5):319-31.

6. Denser CPAC. Indicadores: instrumento para a prática de enfermagem com qualidade. In: Bork AMT, organizador. Enfermagem de excelência: da visão a ação. Rio de Janeiro (RJ): Guanabara Koogan; 2003. p.89-100.

7. Kurcgant $\mathrm{P}$, Tronchin DR, Melleiro MM. A construção de indicadores de qualidade para a avaliação de recursos humanos nos serviços de enfermagem: pressupostos teóricos. Acta Paul Enferm. 2006 JanMar; 19(1):88-91.

8. Donabedian A. The seven pillars of quality. Arch Pathol Lab Méd. 1990 Nov; 114(11):1115-8.

9. Yin, RK. Estudo de caso: planejamento e métodos. Porto Alegre (RS): Bookman; 2005.

10. Organização Nacional de Acreditação [página na internet]. Organizações Certificadas [acesso 2007 Set 15]. Disponível em: https://www.ona.org. br/OrganizacoesCertificadas

11. Agência Nacional de Vigilância Sanitária (BR). Resolução n. 15, de 15 de março de 2012. Dispõe sobre requisitos de boas práticas para o processamento de produtos para saúde e dá outras providências. Brasília (DF): ANVISA; 2012.

12. Padoveze MC, Quelha MCF, Nakamura MHY. Esterilização por métodos físicos. In: Graziano KU, Silva A, Psaltikidis EM, organizadoras. Enfermagem em centro de material e esterilização. Barueri (SP): Manole; 2011. p. 109-130.

13. Rutala WA, Weber DJ, Healthcare Infection Control Practices Advisory Committee (HICPAC). Guideline for disinfection and sterilization in healthcare facilities, 2008. [online]. Chapel Hill: CDC; 2008 [acesso em 2013 Jan 29]. Disponível em: http://www.cdc.gov/hicpac/pdf/guidelines/ Disinfection_Nov_2008.pdf

14. Graziano KU, Lacerda RA, Turini RNT, Bruna CQM, Silva CPR, Schmitt C, et al. Indicadores de avaliação do processamento de artigos odontomédico-hospitalares: elaboração e validação. Rev Esc Enferm USP. 2009 Dez; 43(Esp2):1174-80

15. Malik AM, Telles JP. Hospitais e programas de qualidade no estado de São Paulo. Rev Admin Empres. 2001 Jul-Set; 41(3):51-9.

16. Junior AE. Uso de indicadores de saúde na gestão de hospitais públicos da Região Metropolitana de São Paulo. Núcleo de pesquisas e Publicações, Escola de Administração de empresas - Fundação Getulio Vargas. Série Relatórios de Pesquisa. Relatório 9; 2004.

17. Machado RR, Gelbcke FL. Que brumas impedem a visibilização do Centro de Material e Esterilização? Texto contexto Enferm [online]. 2009 [acesso 2013 Jan 29]; 18(2):347-54. Disponível em: http:/ /www. scielo.br/scielo.php?script=sci_arttext\&pid=S010407072009000200019\&lng=pt\&nrm=iso 